\section{Overseas Students in Great Britain}

In the review of Mr. E. Child's book "The Tools of the Chemist" in NATURE of November 9, p. 604, reference was made to the necessity of bringing students from overseas to Great Britain after the War ; and the suggestion was made that this should form part of the work of the British Council. Prof. B. Ifor Evans, Educational Adviser to the British Council, now writes that, since 1935, the British Council has been inviting students from overseas to undertake courses and research at British universities and similar institutions ; indeed, had not the War prevented it, nearly 250 students from twenty-one countries would have commenced their studies in Great Britain in. October 1939. Drawn from practically all countries of Europe, many countries of South America, the Dominions and Colonies and the Near and Middle East, these students would have studied or carried out research in a great variety of scientific and humanistic subjects, including medicine, engineering, agriculture, law, philology, economics, sociology, physics, education, English language and literature, etc. Such activity is continuing so far as possible, even during the War; last year 143 students from overseas studied in the United Kingdom under the auspices of the British Council, and after the War it is hoped to give a considerable extension to this work.

\section{The American Contribution to a New Order}

IN an address at Southampton, Long Island, on September 1 on "Our United States in this Backward Moving World", Dr. N. Murray Butler asserted that the human race is witnessing the greatest and most far-reaching revolution which history records. This revolution is primarily the outgrowth of economic problems and ambitions, and he urged that the substitution of information for knowledge as a result of the influence of the Press and the radio has made it of vital importance to look beneath the surface of things. The arrest at the beginning of this century of progress towards a prosperous and contented and peaceful world, organized for the preservation and protection of law and order, was due to the incompetence and failure of the democracies, especially France, Great Britain and the United States, to understand the new economic and political forces at work and to co-operate for their control and direction in a manner which would preserve and protect the democratic system of economic, social and political order, as well as the free institutions built upon that order.

In these critical years the democracies lacked conspicuously the able, constructive and courageous leadership required. Discussing the causes for the absence of co-operation, courage and vision in the democracies, Dr. Butler pointed out that all those important problems and policies which have been looked upon in the United States as national or domestic are now absorbed into and made part of the world revolution. This change must be recognized, as well as the danger incurred, for the public opinion and elected political representatives in the United
States come under the pressure of closely organized and persistent minority groups, unconcerned with principles or the public welfare.

Public opinion, moreover, is the unseen product of education and practical experience. Education, in turn, is the function of the family, the church and the school in co-operation, The neglect or failure of the family in its guiding influence and discipline, and of the church in its religious instruction, has given an impossible burden to the schools, and these conditions must be corrected if the American people are not to play into the hands of the advocates of a totalitarian State. Dr. Butler further referred to the signs of an invapacity to understand and to interpret liberty, or to distinguish it from licence. The limit between liberty and licence must be recognized and observed if liberty itself is to remain. In this backward-moving world, however, Dr. Butler believes that leadership towards return to a new and forwardmoving world may well rest with the United States, despite its shortcomings and failures. The federal principle it has established must be applied further if a new, prosperous and peaceful world is to be established upon the wreck of the present order.

\section{Engineers and Reconstructions}

AT a meeting of the Junior Institution of Engineers on December 14, Viscount Falmouth in his presidential address pointed out that, after the War, a heavy weight of responsibility will still lie on the shoulders of the engineer, for, though the planning of reconstruction may be in other hands, the methods and the actual work of restoring a stricken world will fall largely to the man of science and the engineer. When the Napoleonic wars left England and Europe in a state of profound exhaustion, it must have seemed impossible that recovery could take place for a long time. But depression lifted gradually, first in Great Britain and later in Europe, largely due to the development by James Watt of his steam engine. After 1918, Great Britain was again exhausted by the immensity of her effort; but although we had several severe economic storms to weather, yet, on the whole, our recovery was fairly rapid. Although this time we did not have an entirely new prime mover to come to our assistance, as we had in 1815, yet the years 1918-30 saw the large steam turbine reach a high state of efficiency and trustworthiness. This, doubtless, contributed to the national recovery. The fact that power from a thermal unit can be sold as cheaply as power from a hydro-electric station, has enabled Great Britain, with its small water-power resources, still to compete with countries better placed in this respect.

To-day we ask ourselves if there is any form of prime mover which is likely to do for our generation what the Watt engine did for the years after 1815 and the Parsons steam turbine did from 1918 onwards. Possibly the high compression internal combustion engine may be an answer. This has a high thermal efficiency, and, as now constructed, is most trustworthy. The fact that it can operate on either oil or gas without even changing the com- 